\title{
Peningkatan Kompetensi Guru Melalui Workshop Model Integrasi Terpadu Literasi Sains Dan Pendidikan Karakter Dalam Pembelajaran IPA
}

\author{
Alif Yanuar Zukmadini ${ }^{1}$, Bhakti Karyadi ${ }^{2}$, Syaiful Rochman ${ }^{3}$ \\ ${ }^{1}$ Prodi S-1 Pendidikan Biologi, Fakultas Keguruan dan Ilmu Pendidikan, Universitas Bengkulu \\ ${ }^{2,3}$ Prodi S-1 Pendidikan IPA, Fakultas Keguruan dan Ilmu Pendidikan, Universitas Bengkulu \\ 1ayzukmadini@unib.ac.id \\ ²karyadi@unib.ac.id \\ srochman@unib.ac.id
}

\begin{abstract}
ABSTRAK
Berkaitan dengan upaya peningkatan literasi sains dan pendidikan karakter peserta didik, selama ini masalah yang dihadapi oleh guru IPA SMP di kabupaten Bengkulu Tengah adalah kurangnya pengetahuan dan keterampilan guru dalam mengintegrasikan pembelajaran yang bermuatan literasi sains dan Pendidikan karakter di kelas. Selain itu masalah yang dihadapi oleh guru adalah kurangnya kompetensi guru dalam merancang strategi pembelajaran IPA yang menitikberatkan pada peningkatan literasi sains dan pengembangan karakter peserta didik. Melalui kegiatan pengabdian ini, solusi yang dilakukan adalah memberikan pelatihan kepada guru IPA untuk meningkatkan pengetahuan, pemahaman, dan keterampilan dalam merancang, menerapkan, dan mengevaluasi strategi pembelajaran IPA yang mengintegrasikan literasi sains dan pendidikan karakter. Kegiatan ini melibatkan 20 orang guru mata pelajaran IPA yang berasal dari 10 SMP yang ada di kabupaten Bengkulu Tengah. Metode yang digunakan dalam kegiatan ini adalah metode kaji tindak. Hasil evaluasi kegiatan menunjukkan bahwa kegiatan ini mampu meningkatkan kemampuan guru dalam merancang strategi pembelajaran IPA melalui model integrasi literasi sains dan PPK. Kegiatan ini sangat penting sebagai suatu upaya untuk meningkatkan kompetensi mengajar guru IPA.
\end{abstract}

Kata kunci: Model Integrasi, Literasi Sains, Penguatan Pendidikan Karakter, Guru IPA,Pembelajaran IPA

\section{ABSTRACT}

In connection with efforts to increase scientific literacy and character education of students, so far the problem faced by science teachers at junior high schools in Bengkulu Tengah district is the lack of knowledge and skills of teachers in integrating learning that contains scientific literacy and character education in the classroom. In addition, the problem faced by teachers is the lack of teacher competence in designing science learning strategies that focus on increasing scientific literacy and developing the character of students. Through this service activity, the solution is to provide training to science teachers to improve knowledge, understanding, and skills in designing, implementing, and evaluating science learning strategies that integrate scientific literacy and character education. This activity involved 20 science teachers from 10 junior high schools in Bengkulu Tengah district. The method used in this activity is the follow-up study method. The results of the activity evaluation showed that this activity was able to improve the ability of teachers in designing science learning strategies through the integration of scientific literacy and PPK models. This activity is very important as an effort to improve the teaching competence of science teachers.

Keywords: Reading Interest, Community Based Research, School Literacy Movement

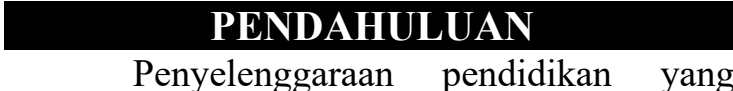
berkualitas harus melibatkan siswa untuk belajar secara aktif sehingga mengarah pada terbentuknya nilai-nilai yang dibutuhkan dalam menjalani kehidupannya (Sani, 2014). Dalam menyelenggarakan pendidikan, termasuk di dalamnya kegiatan perencanaan, pelaksanaan, hingga evaluasi pembelajaran memerlukan kinerja guru yang terintegrasi dalam empat kompetensi yaitu kompetensi pedagogik, sosial, kepribadian, dan profesional. Keempat kompetensi tersebut merupakan standar kompetensi wajib yang perlu dimiliki oleh seorang guru dalam mengajarkan mata pelajarannya (UU No 14 , 2003).

Terdapat 14 kompetensi inti guru 
mata pelajaran IPA SMP/MTs beberapa di antaranya adalah 1) kemampuan untuk memahami proses berpikir IPA dalam mempelajari proses dan gejala alam 2) menerapkan konsep, hukum, dan teori IPA untuk menjelaskan berbagai fenomena alam 3) menjelaskan penerapan hukum-hukum IPA dalam teknologi terutama yang dapat ditemukan dalam kehidupan sehari-hari. Kompetensi tersebut sangat erat kaitannya dengan upaya peningkatan keterampilan literasi sains pada peserta didik (Permendiknas No 16, 2007)

Literasi sains merupakan pengetahuan dan kecakapan ilmiah untuk mampu mengidentifikasi pertanyaan, memperoleh pengetahuan baru, menjelaskan fenomena ilmiah, serta mengambil simpulan berdasarkan fakta, memahami karakteristik sains, menyadari bagaimana sains dan teknologi membentuk lingkungan alam, intelektual, dan budaya, serta meningkatkan kemauan untuk terlibat dan peduli terhadap isu-isu yang terkait sains (OECD, 2015). Prinsip dasar literasi sains diantaranya 1) kontekstual, sesuai dengan kearifan lokal dan perkembangan zaman 2) Pemenuhan kebutuhan sosial, budaya, dan kenegaraan 3) Sesuai dengan standar mutu pembelajaran yang sudah selaras dengan pembelajaran abad XXI 4) Holistik dan terintegrasi dengan beragam literasi lainnya dan 5) Kolaboratif dan partisipatif (Kemendikbud, 2017).

Literasi sains dalam pembelajaran di Indonesia dapat diajarkan pada pelajaran IPA, Biologi, Fisika, atau bahkan mata pelajaran lain. Fakta hasil PISA 2015 menunjukkan ratarata nilai sains negara OECD adalah 493, sedangkan Indonesia baru mencapai skor 403. Nilai tersebut menunjukkan bahwa literasi sains di Indonesia masih tergolong rendah. Hasil studi pendahuluan yang dilakukan oleh tim pengabdian diketahui bahwa pembelajaran IPA di SMP Kabupaten Bengkulu Tengah masih diajarkan secara terpisah dengan guru yang berbeda antara pelajaran Biologi, Kimia, dan Fisika. Akibatnya guru mata pelajaran IPA yang seharusnya mampu menyajikan materi secara utuh dan saling terintegrasi merasa kesulitan dalam menguasai materi tersebut. Jika melihat esensinya, literasi sains tidak hanya berperan penting dalam pembentukan pola pikir dan perilaku manusia, melainkan juga menciptakan manusia yang berkarakter agar peduli tehadap diri sendiri, masyarakat dan alam semesta (Kemendikbud, 2017).

Fakta di lapangan menunjukkan contoh perilaku peserta didik yang berdampak dari adanya krisis karakter dan dirasa erat hubungannya dengan rendahnya kemampuan siswa memahami sains tidak hanya sebagai sumber solusi melainkan juga sumber resiko. Misalnya kurangnya kesadaran siswa terhadap kebersihan lingkungan, merokok, bolos pada jam kelas, terjerumus ke dalam pergaulan bebas, dan masih banyak perilaku negatif lainnya. Oleh sebab itu, penyelenggaraan pendidikan sebaiknya tidak hanya menekankan pada konsep pengetahuan dan keterampilan saja, melainkan perlu didukung dengan upaya pengembangan dan penguatan karakter peserta didik (Kemendikbud, 2017).

Salah satu upaya yang dapat dilakukan untuk meningkatkan literasi sains dan pendidikan karakter di sekolah adalah dengan memberikan pembelajaran yang bermuatan literasi sains (Dragoş \& Mih, 2015) serta penguatan pendidikan karakter kepada peserta didik (Budhiman, 2017). Untuk dapat menerapkan pembelajaran yang berorientasi literasi sains di sekolah, maka perlu didukung oleh sikap positif dan kemampuan mengajar yang baik bagi guru sains (Kemendikbud, 2017). Menurut Kemendikbud (2017) penguatan pendidikan karakter (PPK) memiliki lima nilai utama yang menjadi prioritas dalam gerakan penguatan pendidikan karakter peserta didik, yaitu nilai religius, nasionalis, mandiri, gotong royong, dan integritas. Pelatihan kegiatan literasi yang dintegrasikan dengan penguatan pendidikan karakter kepada guru IPA merupakan bentuk kegiatan yang tidak bisa dipisahkan dalam mengajarkan konsep dan keterampilan sains saja, melainkan mampu mengembangkan dan menguatkan karakter peserta didik. Oleh sebab itu pembelajaran sains dan penguatan karakter tidak dapat dipisahkan dalam upaya pembentukan nilai dan peningkatan literasi peserta didik.

Guru sekolah menengah dituntut untuk mampu menerapkan berbagai pendekatan, strategi, metode, dan teknik pembelajaran yang mendidik secara kreatif dalam mata pelajaran yang diamp (Permendiknas No 16 Tahun 2007). Dari kompetensi tersebut penting sekali bagi guru untuk menguasai strategi mengajar yang menekankan pada literasi sains dan pendidikan karakter. Dari permasalahan yang dijelaskan, maka tim pengabdian kami berinisiatif untuk merancang suatu model pelatihan terpadu literasi sains dan pendidikan karakter dalam bentuk kegiatan workshop bagi guru IPA di Kabupaten Bengkulu Tengah, Provinsi Bengkulu. 
Tujuan dari kegiatan workshop ini adalah untuk meningkatkan kompetensi mengajar guru IPA, yang capaian kompetensinya meliputi 1) mampu memahami perkembangan kognitif, kepribadian, dan mengidentifikasi bekal mengajar awal peserta didik berdasarkan prinsip-prinsip literasi sains dan nilai-nilai PPK secara terpadu dalam pembelajaran 2) mampu merancang pembelajaran model intergrasi terpadu literasi sains dan nilai-nilai PPK berdasarkan Kompetensi dasar mata pelajaran IPA SMP/MTs 3) mampu menentukan dan menerapkan strategi pembelajaran model intergrasi terpadu literasi sains dan nilai-nilai PPK berdasarkan tuntutan kurikulum.

Pelaksanaan kegiatan pengabdian ini melibatkan FKIP UNIB sebagai lembaga penyelenggara dan berbagai SMP di kabupaten Bengkulu Tengah sebagai institusi asal peserta kegiatan pengabdian. Kelompok musyawarah guru mata pelakaran (MGMP) IPA yang berasal dari beberapa sekolah di Kabupaten Bengkulu Tengah menjadi mitra dalam kegiatan ini. Sekolah yang terdapat di Kabupaten Bengkulu Tengah memiliki guru IPA/Biologi yang akan menjadi peserta dalam kegiatan ini. Guru IPA di Kabupaten Bengkulu Tengah memiliki motivasi yang tinggi untuk mengembangkan kemampuan mengajar, selain itu sekolah di Kabupaten Bengkulu Tengah memiliki fasilitas pembelajaran berupa laboratorium dan alat-alat laboratorium yang mendukung kegiatan pembelajaran IPA berbasis literasi sains.

\section{METODE KEGIATAN}

Kegiatan pelatihan ini menggunakan pendekatan kaji tindak dengan beberapa jenis metode seperti wawancara, observasi, presentasi, simulasi, diskusi, dan tanya jawab. Kegiatan pelatihan dibagi menjadi beberapa tahapan yaitu tahap pendahuluan, tahap pelaksanaan, tahap bimbingan, dan tahap evaluasi. Khalayak sasaran kegiatan ini adalah kelompok musyawarah guru mata pelajaran (MGMP) IPA yang terdiri dari 20 orang guru mata pelajaran IPA yang berasal dari 10 SMP yang ada di Kabupaten Bengkulu Tengah. Tahapan kegiatan tersebut dijelaskan sebagai berikut:

a. Tahap pendahuluan, pada kegiatan ini dilakukan observasi dan wawancara untuk menganalisis kondisi khalayak sasara. Pada tahap ini juga dilakukan persiapan materi mengenai literasi sains dan penguatan pendidikan karakter dalam pembelajaran.

b. Tahap pelaksanaan, pada kegiatan ini fasilitator akan bertindak sebagai pemateri untuk memberikan materi pelatihan dengan menggunakan metode presentasi, simulasi, tanya jawab, dan diskusi. Tahap ini diawali dengan pemberian materi oleh fasilitator kemudian diikuti dengan kegiatan diskusi dan tanya jawab dengan para guru. Materi yang akan diberikan pada kegiatan pelatihan ini yaitu bagaimana cara guru merancang dan menerapkan strategi pembelajaran IPA melalui model integrasi literasi sains dan pendidikan karakter kepada peserta didik

c. Tahap bimbingan, pada kegiatan ini guru diminta untuk membuat rancangan strategi pembelajaran IPA melalui model integrasi literasi sains dan pendidikan karakter. Kegiatan akan diawali dengan mengidentifikasi Kompetensi Inti (KI) dan Kompetensi Dasar (KD) pada dokumen kurikulum mata pelajaran IPA yang memiliki keterkaitan dengan prinsip literasi sains dan PPK, untuk kemudian dirumuskan indikator dan tujuan pembelajarannya. Kemudian guru akan diminta untuk menentukan metode dan model pembelajaran yang tepat. Setelah itu guru diminta membuat rencana pembelajaran yang mengambarkan integrasi terpadu antara literasi sains dan PPK dalam pembelajaran sesuai dengan KD.

d. Tahapan evaluasi, pada kegiatan ini dilakukan evaluasi yang bertujuan untuk menilai dan merefleksi kemampuan guru dalam merancang pembelajaran IPA menggunakan model integrasi terpadu literasi sains dan PPK. Kegiatan evaluasi dilakukan dengan mengobservasi aktivitas guru pada saat kegiatan pelatihan, menilai hasil analisis Rencana Perangkat pembelajaran (RPP), dan meminta guru untuk mengisi kuisioner selama kegiatan workshop.

\section{HASIL \& PEMBAHASAN}

Bentuk kegiatan workshop yang dilakukan merupakan kegiatan pelatihan bagi guru IPA yang bertujuan untuk memberikan 
suatu model integrasi terpadu antara literasi sains dan pendidikan karakter. Model integrasi ini menjelaskan tentang bagaimana cara guru mengembangkan strategi pembelajaran IPA untuk meningkatkan keterampilan literasi sains yang terpadu dengan upaya penguatan pendidikan karakter pada peserta didik. Desain workshop model integrasi terpadu literasi sains dan pendidikan karakter dalam pembelajaran IPA dapat dilihat pada Gambar 1.

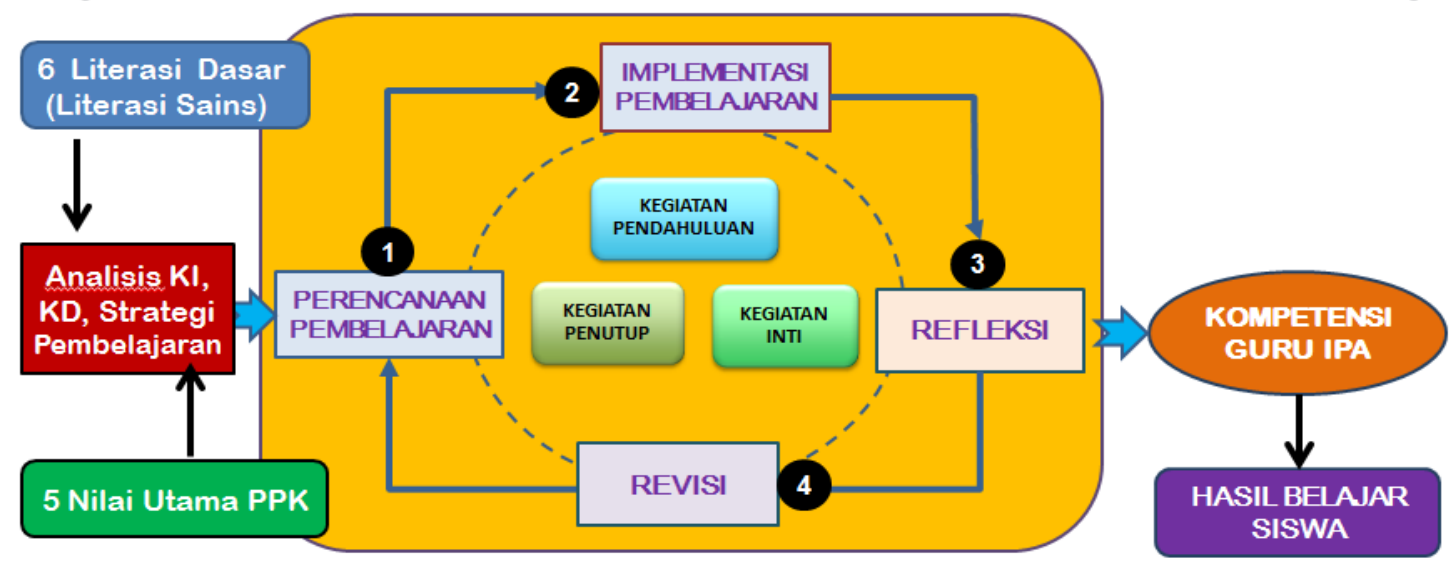

Gambar 1. Model Integrasi Terpadu Literasi Sains dan Penguatan Pendidikan Karakter

Dari model tersebut, langkah-langkah mengintegrasikan literasi sains dan penguatan pendidikan karakter (PPK) dalam pembelajaran IPA dilaksanakan dengan cara:

1. Mengidentifikasi Kompetensi Inti (KI) dan Kompetensi Dasar (KD) yang memiliki keterkaitan dengan prinsip literasi sains dan PPK.

2. Merumuskan indikator dan tujuan pembelajaran berdasarkan; KD yang memiliki keterkaitan dengan prinsip prinsip literasi sains dan PPK.

3. Menyusun strategi pembelajaran dengan memilih metode, model, dan media pembelajaran yang sesuai dengan indikator dan tujuan pembelajaran yang akan dicapai.

4. Merancang Rencana Pembelajaran yang mengambarkan integrasi terpadu antara literasi sains dan PPK dalam pembelajaran sesuai KD.

5. Melaksanakan pembelajaran model integrasi terpadu dalam setiap proses pembelajaran, pada kegiatan pendahuluan, kegiatan inti dan kegiatan penutup.

6. Melaksanakan refleksi dan revisi terhadap rencana pembelajaran dan proses pembelajaran yang telah dilakukan.

Berdasarkan hasil evaluasi kegiatan yang dilakukan terhadap peserta kegiatan pengabdian, diperoleh data kemampuan guru dalam merancang strategi pembelajaran literasi sains terintegrasi dengan PPK. Data hasil evaluasi yang diperoleh berupa persentase kemampuan guru dalam merancang pembelajaran terpadu literasi sains dan pendidikan karkter, serta deskripsi analisis pembelajaran bermuatan PPK dari RPP yang digunakan guru dalam kegiatan pembelajaran di kelas. Data persentase kemampuan guru dalam merancang pembelajaran berorientasi literasi sains diperoleh dari hasil observasi dan angket yang diisi oleh setiap guru pada saat akhir kegiatan pelatihan yang dapat dilihat pada Tabel 1 .

Tabel 1. Persentase Kemampuan Guru Dalam Merancang Pembelajaran Berorientasi Literasi Sains

\begin{tabular}{clcc}
\hline No & \multicolumn{1}{c}{ Indikator rancangan evaluasi } & Persentase (\%) & Kriteria \\
\hline 1 & Pengetahuan guru mengenai literasi sains & 76,47 & Sangat baik \\
\hline 2 & $\begin{array}{l}\text { Pengetahuan guru mengenai pembelajaran berliterasi } \\
\text { sains }\end{array}$ & 70,58 & Baik \\
\hline 4 & Kemampuan guru dalam mengembangkan strategi & 69,11 & Baik \\
\hline
\end{tabular}




\begin{tabular}{|c|c|c|c|}
\hline & pembelajaran berorientasi literasi sains & & \\
\hline 5 & $\begin{array}{l}\text { Kemampuan guru dalam menggunakan media } \\
\text { pembelajaran untuk meningkatkan literasi sains siswa }\end{array}$ & 72,05 & Baik \\
\hline 6 & $\begin{array}{l}\text { Kemampuan guru untuk menerapkan pembelajaran } \\
\text { berliterasi sains pada siswa }\end{array}$ & 73,52 & Baik \\
\hline 7 & $\begin{array}{l}\text { Kemampuan guru dalam mengadakan inovasi } \\
\text { pembelajaran yang berorientasi literasi sains }\end{array}$ & 72,05 & Baik \\
\hline 8 & $\begin{array}{l}\text { Kemampuan guru dalam mensimulasikan } \\
\text { pembelajaran berliterasi sains }\end{array}$ & 75 & Baik \\
\hline 9 & $\begin{array}{l}\text { Kemampuan guru dalam memilih metode dan model } \\
\text { yang menekankan pada aspek literasi sains }\end{array}$ & 73,52 & Baik \\
\hline 10 & $\begin{array}{l}\text { Kemampuan menjelaskan materi yang mengandung } \\
\text { unsur literasi sains }\end{array}$ & 73,52 & Baik \\
\hline 12 & $\begin{array}{l}\text { Kemampuan guru dalam mengembangkan potensi } \\
\text { peserta didik dalam pembelajaran berliterasi sains }\end{array}$ & 70,58 & Baik \\
\hline 13 & $\begin{array}{l}\text { Kemampuan guru dalam mengevaluasi kemampuan } \\
\text { literasi sains pada peserta didik }\end{array}$ & 70,58 & Baik \\
\hline
\end{tabular}

Data mengenai hasil kemampuan guru dalam memberikan penguatan pendidikan karakter (PPK) berbasis kelas dinilai dari hasil kerja kelompok guru dalam menganalisis nilai-nilai karakter yang terdapat pada komponen RPP. Hasil analisis tersebut dapat dilihat pada dilihat pada Tabel 2.

Tabel 2. Hasil Analisis Nilai Karakter Pada Komponen RPP

\begin{tabular}{|c|c|c|c|c|c|c|}
\hline \multirow{2}{*}{$\begin{array}{c}\text { Kelompok } \\
\text { Guru }\end{array}$} & \multirow[t]{2}{*}{ Kompetensi Dasar } & \multicolumn{4}{|c|}{ Nilai karakter pada komponen RPP } & \multirow{2}{*}{$\begin{array}{l}\text { Nilai Utama } \\
\text { PPK }\end{array}$} \\
\hline & & Tujuan & Keg. Awal & Keg. Inti & $\begin{array}{l}\text { Keg. } \\
\text { Akhir }\end{array}$ & \\
\hline 1 & $\begin{array}{l}\text { Menganalisis cara } \\
\text { makhluk hidup } \\
\text { menyesuaikan diri } \\
\text { dengan lingkungan }\end{array}$ & $\begin{array}{l}\text { Rasa ingin } \\
\text { tahu, } \\
\text { kerjasama } \\
\text { Peduli }\end{array}$ & $\begin{array}{l}\text { Rasa ingin } \\
\text { tahu }\end{array}$ & $\begin{array}{l}\text { Kerjasama } \\
\text { Peduli }\end{array}$ & Peduli & Integritas \\
\hline 2 & $\begin{array}{l}\text { Melakukan } \\
\text { percobaan rangkaian } \\
\text { listrik sederhana } \\
\text { secara seri dan } \\
\text { paralel }\end{array}$ & $\begin{array}{l}\text { Displin } \\
\text { Percaya } \\
\text { diri, Teliti }\end{array}$ & Disiplin & $\begin{array}{l}\text { Percaya diri } \\
\text { Cermat }\end{array}$ & Teliti & Kemandirian \\
\hline 3 & $\begin{array}{l}\text { Menerapakan konsep } \\
\text { pengukuran berbagai } \\
\text { besaran dengan } \\
\text { menggunakan satuan } \\
\text { standar (baku) }\end{array}$ & $\begin{array}{l}\text { Rasa ingin } \\
\text { tahu, } \\
\text { mandiri, } \\
\text { kreatif }\end{array}$ & $\begin{array}{l}\text { Religius, } \\
\text { rasa ingin } \\
\text { tahu }\end{array}$ & $\begin{array}{l}\text { Rasa ingin } \\
\text { tahu, teliti, } \\
\text { jujur, } \\
\text { kreatif, } \\
\text { kerjasama }\end{array}$ & $\begin{array}{l}\text { Tanggung } \\
\text { jawab, } \\
\text { jujur }\end{array}$ & Integritas \\
\hline 4 & $\begin{array}{l}\text { Menghubungkan } \\
\text { sistem reproduksi } \\
\text { pada manusia dan } \\
\text { gangguan pada } \\
\text { sistem reproduksi } \\
\text { dengan penerapan } \\
\text { pola hidup yang } \\
\text { menunjang kesehatan } \\
\text { reproduksi. }\end{array}$ & $\begin{array}{l}\text { Mandiri, } \\
\text { rasa ingin } \\
\text { tahu, } \\
\text { berpikir } \\
\text { kritis, } \\
\text { kreatif. }\end{array}$ & $\begin{array}{l}\text { Religius, } \\
\text { disiplin, } \\
\text { semangat, } \\
\text { berpikir } \\
\text { kritis. }\end{array}$ & $\begin{array}{l}\text { Rasa ingin } \\
\text { tahu, } \\
\text { mandiri, } \\
\text { disiplin, } \\
\text { teliti, } \\
\text { berpikir } \\
\text { kritis, } \\
\text { kreatif, } \\
\text { gotong } \\
\text { royong, } \\
\text { tanggung } \\
\text { jawab, } \\
\text { demokratis }\end{array}$ & $\begin{array}{l}\text { Berpikir } \\
\text { kritis, } \\
\text { kreatif, } \\
\text { mengharg } \\
\text { ai prestasi }\end{array}$ & $\begin{array}{l}\text { Gotong } \\
\text { Royong }\end{array}$ \\
\hline
\end{tabular}




\begin{tabular}{|c|c|c|c|c|c|c|}
\hline 5 & $\begin{array}{l}\text { Menerapkan konsep } \\
\text { pengukuran berbagai } \\
\text { besaran dengan } \\
\text { menggunakan satuan } \\
\text { baku }\end{array}$ & $\begin{array}{l}\text { Rasa ingin } \\
\text { tahu, }\end{array}$ & $\begin{array}{l}\text { Religius, } \\
\text { rasa ingin } \\
\text { tahu, }\end{array}$ & $\begin{array}{l}\text { Rasa ingin } \\
\text { tahu, } \\
\text { kerjasama, } \\
\text { teliti }\end{array}$ & $\begin{array}{l}\text { Tanggung } \\
\text { jawab, } \\
\text { gotong } \\
\text { royong }\end{array}$ & Integritas \\
\hline 6 & $\begin{array}{l}\text { Memahami } \\
\text { karakteristik zat serta } \\
\text { perubahan fisika dan } \\
\text { kimia pada zat yang } \\
\text { dapat dimanfaatkan } \\
\text { untuk kehidupan } \\
\text { sehari-hari }\end{array}$ & $\begin{array}{l}\text { Rasa ingin } \\
\text { tahu }\end{array}$ & $\begin{array}{l}\text { Religius, } \\
\text { tolerensi, } \\
\text { rasa ingin } \\
\text { tahu, } \\
\text { semangat }\end{array}$ & $\begin{array}{l}\text { Kerja sama, } \\
\text { jujur, teliti, } \\
\text { tekun, } \\
\text { berani }\end{array}$ & $\begin{array}{l}\text { Tanggung } \\
\text { jawab, } \\
\text { percaya } \\
\text { diri }\end{array}$ & Integritas \\
\hline
\end{tabular}

Selain dilakukan evaluasi dari angket dan RPP, juga dilakukan observasi aktivitas guru dalam merancang pembelajaran dengan model integrasi literasi sains dan pendidikan karakter selama kegiatan pelatihan. Hasil observasi tersebut dapat dilihat pada Tabel 3.

\begin{tabular}{|c|c|c|c|c|}
\hline No & Aspek observasi & Ya & Tidak & Keterangan \\
\hline 1 & $\begin{array}{l}\text { Jenis literasi dan nilai-nilai } \\
\text { karakter yang dipilih sesuai } \\
\text { dengan KD }\end{array}$ & $\sqrt{ }$ & & $\begin{array}{l}\text { - Literasi yang dipilih tidak hanya } \\
\text { menekankan pada literasi sains, } \\
\text { melainkan juga terintegrasi dengan } \\
\text { literasi membaca } \\
\text { - Pada awalnya guru ingin memasukkan } \\
\text { seluruh nilai-nilai nilai-nilai karakter } \\
\text { pada RPP, namun setelah diberikan } \\
\text { pemahaman materi bahwasanya cukup } 1 \\
\text { nilai karakter dalam masing-masing } \\
\text { langkah pembelajaran }\end{array}$ \\
\hline 2 & $\begin{array}{l}\text { Menggunakan moda/bahan } \\
\text { literasi yang dapat } \\
\text { mengembangkan karakter }\end{array}$ & $\sqrt{ }$ & & $\begin{array}{l}\text { Literasi sains dapat mengembangkan } \\
\text { karakter religius, tanggung jawab, disiplin, } \\
\text { dan rasa ingin tahu }\end{array}$ \\
\hline
\end{tabular}

\begin{tabular}{|c|c|c|c|}
\hline 3 & $\begin{array}{l}\text { Menggunakan metode/model } \\
\text { pembelajaran yang } \\
\text { menyenangkan, serta kaya literasi } \\
\text { terkait dengan nilai karakter }\end{array}$ & $\sqrt{ }$ & $\begin{array}{l}\text { Model pembelajaran yang dikembangkan } \\
\text { berupa model pembelajaran PBL, } \\
\text { Kooperatif, Siklus belajar 5E, dan } \\
\text { discovery learning }\end{array}$ \\
\hline 4 & $\begin{array}{l}\text { Menggunakan komunikasi efektif } \\
\text { dalam upaya menumbuhkan nilai- } \\
\text { nilai karakter }\end{array}$ & $\sqrt{ }$ & $\begin{array}{l}\text { Nilai karakter tidak hanya tertulis di RPP, } \\
\text { pada dasarnya penanaman nilai karakter } \\
\text { sudah dilakukan namun diperlukan } \\
\text { penguatan kepada peserta didik mengapa } \\
\text { kegiatan berorientasi karakter perlu } \\
\text { dilakukan }\end{array}$ \\
\hline 5 & $\begin{array}{l}\text { Memanfaatkan bahan literasi } \\
\text { secara efektif dengan melibatkan } \\
\text { siswa secara fisik dan psikis }\end{array}$ & $\sqrt{ }$ & $\begin{array}{l}\text { Menggunakan sumber belajar, alam, dan } \\
\text { alat-alat praktikum }\end{array}$ \\
\hline 6 & $\begin{array}{l}\text { Melakukan kegiatan untuk } \\
\text { memaparkan/mempublikasikan } \\
\text { karya }\end{array}$ & $\sqrt{ }$ & $\begin{array}{l}\text { Karya hasil pembelajaran dilakukan } \\
\text { melalui mading sekolah dan media sosial }\end{array}$ \\
\hline
\end{tabular}

Dari kegiatan pengabdian yang dilakukan terdapat peningkatan kemampuan guru dalam merancang pembelajaran IPA melalui model terpadu literasi sains dan PPK. Berdasarkan hasil survei yang dilakukan sebelum guru mengikuti pelatihan diketahui bahwa pemahaman guru mengenai literasi sains masih rendah. Selain itu kemampuan guru dalam mengintegrasikan pendidikan karakter di sekolah masih kurang. Selama ini, kegiatan penguatan pendidikan karakter hanya 
diintegrasikan pada saat kegiatan tertentu misalnya saat membuka pelajaran yang dilakukan melalui kegiatan berdoa. Padahal kegiatan penguatan pendidikan karakter tidak hanya dilakukan pada kegiatan tertentu melainkan dapat diintegrasikan pada seluruh kegiatan pembelajaran.

Untuk meningkatkan literasi sains pada peserta didik khususnya pada tingkatan mata pelajaran IPA SMP, peranan guru dalam pendidikan dan pembelajaran merupakan hal penting. Hal ini dikarenakan peranan guru dalam Gerakan Literasi Nasional (GLN) adalah menyusun RPP serta melaksanakan pembelajaran dan penilaian yang mengintegrasikan kegiatan GLN; menggunakan metode pembelajaran yang mengembangkan kemampuan berpikir kritis, kreatif, komunikatif, dan kolaboratif; membangun lingkungan belajar yang mendorong peserta didik memiliki semangat berliterasi (Kemendikbud, 2017).

Lliterasi sains merupakan kompetensi penting dalam membangun kesejahteraan manusia saat ini dan saat yang akan datang. Harapannya literasi sains yang dibelajarkan di lingkungan kelas tidak hanya menjadi dapat menjadi pengetahuan mengenai sains saja melainkan dapat membantu siswa memahami bagaimana peranan sains serta mampu mengambil keputusan terhadap dampak yang ditimbulkannya. Hal ini sesuai dengan (OECD, 2015) yang menyatakan bahwa literasi sains meliputi pengetahuan dan kecakapan ilmiah untuk mampu mengidentifikasi pertanyaan, memperoleh pengetahuan baru, menjelaskan fenomena ilmiah, mengambil simpulan berdasar fakta, memahami karakteristik sains, kesadaran bagaimana sains dan teknologi membentuk lingkungan alam, intelektual, dan budaya, serta kemauan untuk terlibat dan peduli terhadap isu-isu yang terkait sains. Hal ini sejalan dengan (McFarlane, 2013) yang menyatakan bahwa dalam pembelajaran sains, siswa perlu diajari untuk memahami bahwa sains memiliki nilai-nilai yang mengarah pada tindakan sosial untuk menyelesaikan permasalahan yang timbul akibat perkembangan ilmu sains itu sendiri. Oleh sebab itu pemahaman akan sains yang diajarkan melalui satuan pendidikan perlu diiringi dengan adanya penguatan pendidikan karakter peserta didik. Menurut Budhiman (2007), implementasi dari kegiatan penguatan karakter dapat dilakukan melalui kegiatan berbasis kelas yang salah satu upayanya melibatkan penguatan kapasitas guru ketika mengajar di kelas.

Adanya program pelatihan bagi guru dalam merancang pembelajaran yang menekankan integrasi literasi sains dan pendidikan karakter mampu memberikan respon positif bagi guru untuk menerapkannya pada peserta didik di kelas, sekolah maupun masyarakat. Hal ini sesuai dengan (Dragoş \& Mih, 2015) yang menyatakan bahwa program pelatihan bagi guru dalam membelajarkan literasi sains juga perlu memperhatikan sosial budaya atau karakteristik siswanya, sehingga guru mampu mengembangkan konteks pembelajaran yang sesuai dengan situasi dalam kehidupan bermasyarakat. Hal ini sejalan dengan Gerakan Literasi Nasional (GLN) yang dilakukan Kemendikbud bahwasanya salah satu sasaran umum dalam mengimplementasikan gerakan literasi adalah melaksanakan kegiatan literasi yang terintegrasi dengan penguatan pendidikan karakter (PPK) dan Kurikulum, dimana salah satu strategi yang dilakukan adalah dengan memberikan pelatihan kepada guru dalam memberikan metode pembelajaran berbasis masalah dan berbasis proyek.

Dalam merancang pembelajaran berbasis literais sains, dari hasil pelatihan diketahui bahwa strategi pembelajaran yang dirancang oleh guru untuk meningkatkan literasi sains adalah model pembelajaran PBL, Kooperatif, Siklus belajar 5E, dan discovery learning. Jenis model pembelajaran yang paling mudah dirancang oleh guru untuk membelajarkan literasi sains kepada siswa adalah model discovery learning, hal ini dikarenakan model pembelajaran tersebut mampu melatih siswa untuk melakukan kerja ilmiah seperti mengidentifikasi masalah dan bekerja sama untuk merancang solusi terhadap permasalahan yang ada. Hal tersebut sesuai dengan (Dewi et al., 2017) yang menyatakan bahwa model pembelajaran discovery learning memang telah terbukti dapat meningkatkan literasi sains pada siswa SMP terutama pada mata pelajaran IPA. Model pembelajaran yang dipilih guru merupakan model pembelajaran dengan pendekatan saintifik. Menurut (Asyhari, 2015) pembelajaran saintifik dapat meningkatkan kemampuan literasi sains siswa, karena pembelajaran ini dapat merangsang ketertarikan siswa kepada isu ilmiah, meningkatkan inkuiri ilmiah, dan mendorong rasa tanggung jawab siswa terhadap lingkungan sekitarnya. Selain pendekatan saintifik terdapat beberapa pendekatan 
pembelajaran lain yang dapat dilakukan oleh guru untu meningkatkan literasi sains pada siswa seperti pendekatan inkuiri, pendekatan STEM, dan pendekatan Argument Driven Inquiry (ADI) (Herlanti et al., 2019).

Untuk kegiatan penguatan pendidikan karakter, pada dasarnya dapat dilakukan di semua mata pelajaran. Salah satunya adalah mata pelajaran IPA. Di mata pelajaran IPA, banyak nilai-nilai karakter yang ditanamkan. Hal ini sesuai dengan Triatmanto (2010) pada prinsipnya semua mata pelajaran dapat digunakan sebagai alat untuk mengembangkan semua karakter peserta didik, namun agar tidak terjadi tumpang-tindih dan terabaikannya salah satu karakter yang akan dikembangkan, perlu dilakukan pemetaaan berdasarkan kedekatan materi dengan karakter yang akan dikembangkan. Integrasi pendidikan karakter bukan saja dapat dilakukan dalam materi pelajaran, namun teknik dan metode mengajar dapat pula digunakan sebagai alat pendidikan karakter. Oleh karena itu karakter merupakan istilah yang menunjuk kepada aplikasi nilainilai kebaikan dalam bentuk tingkah laku yang dimiliki seseorang (Sunarti, 2005).

Kegiatan pelatihan/workshop model terpadu yang mengintegrasikan literasi sains dan pendidikan karakter pada mata pelajaran IPA SMP merupakan salah satu upaya yang dilakukan untuk meningkatkan kompetensi pedagogik guru, selain itu kegiatan ini juga diharapkan dapat meningkatkan dan mengembangan 3 kompetensi utama lainnya. Hal ini sejalan dengan (Emaliana, 2020) bahwa salah satu upaya untuk meningkatkan kompetensi pedagogik, sosial, kepribadian, dan profesional guru mata pelajaran adalah dengan memberikan pelatihan dan pendampingan pada kelompok Musyawarah Guru Mata Pelajaran (MGMP).

Berdasarkan hasil kegiatan pelatihan, diperoleh hasil bahwa pemahaman dan keterampilan guru dalam memberikan pembelajaran IPA dengan menekankan pada literasi sains dan pendidikan karakter mengalami peningkatan. Dalam kegiatan ini guru terlebih dahulu diberikan pemahaman mengenai konsep literasi sains, kemudian fasilitator mendemontrasikan pembelajaran, dan selanjutnya guru diminta untuk merumuskan strategi pembelajaran. Langkahlangkah kegiatan pelatihan merupakan contoh pendekatan yang sangat membantu guru dalam meningkatkan pengetahuan dan keterampilan dalam menerapkan pembelajaran berorientasi literasi sains. Hal ini sesuai dengan (Rubini et al., 2018) yang menyatakan bahwa terdapat 8 langkah pendekatan pembelajaran yang dapat digunakan untuk memberikan pelatihan mengenai pemahaman guru tentang literasi sains dan bagaimana mengintegrasikannya ke dalam pembelajaran yaitu 1) membangun persepsi umum mengenai literasi sains, analisis integrasi sains berdasarkan kurikulum saat ini dan analisis pembelajaran, presentasi, mendesain rencana pembelajaran dalam grup, simulasi, mendesain rencana pembelajaran secara individu, evaluasi-refleksi, dan reward. Pendekatan pelatihan yang dilakukan dengan teknik tersebut dapat meningkatkan kemampuan guru dalam mengembangkan pembelajaran dan pemahaman terhadap konsep sains yang terintegrasi.

Pelatihan penguatan pendidikan karaktkter yang terintegrasi dengan pelatihan pembelajaran berliterasi sains ini tidak hanya memberikan dampak positif terhadap kemampuan guru dalam membelajaran IPA, namun terdapat nilai-nilai yang ada dasarnya dapat diintegrasikan dalam pembelajaran baik pada saat mengidentifikasi permasalahan yang akan dipelajari dan mencari solusi terhadap permasalahan tersebut. Pada intinya kegiatan penguatan pendidikan karakter tidak hanya dilakukan dalam lingkungan kelas saja melainkan juga dapat dilakukan pada kegiatankegiatan di luar kelas. Menurut (Kholifah, 2020) guru memiliki peran yang sangat penting dalam mengembangkan karakter peserta didik melalui kegiatan pembelajaran, pembiasaan, budaya sekolah, ekstrakurikuler dan visi misi sekolah. Kegiatan pelatihan kepada guru sangat bermanfaat dalam pengembangan keterampilan guru, hal ini sejalan dengan (Faisal et al., 2020) yang menyatakan bahwa kegiatan pelatihan kepada guru merupakan suatu bentuk implementasi teori, pengetahuan, dan keterampilan dalam menyelesaikan masalah-masalah pembelajaran di lapangan.

\section{UCAPAN TERIMA KASIH}

Dalam pelaksanaan kegiatan pengabdian ini, kami mengucapkan terima kasih kepada Lembaga Penelitian dan Pengabdian Masyarakat (LPPM) Universitas Bengkulu yang telah memberikan bantuan penyelenggaraan kegiatan melalui dana PNBP UNIB Tahun 2019 skim Pengabdian Pembinaan UNIB dengan Nomor Kontrak 1561/UN30.15/PM/2019. 


\section{KESIMPULAN \& SARAN}

Kesimpulan dari kegiatan ini adalah terdapat peningkatan pengetahuan dan keterampilan guru dalam merancang pembelajaran berliterasi sains dan pendidikan karakter. Workshop ini merupakan salah satu model pelatihan terbaru yang bertujuan untuk mengembangkan kompetensi guru IPA dalam merancang strategi pembelajaran IPA bermuatan pendidikan karakter dan literasi sains. Model pelatihan ini dapat menjembatani upaya peningkatan literasi sains dan penguatan pendidikan karakter kepada peserta didik yang terintegrasi dalam satu kegiatan, dengan harapan dapat diterapkan pada pembelajaran di kelas.

Saran dari pengabdian ini adalah kegiatan pelatihan model integrasi literasi sains dan pendidikan karakter dapat dipluas tidak hanya pada kegiatan berbasis pembelajaran di kelas, melainkan juga diperluas untuk kegiatan berbasis sekolah.

\section{DAFTAR PUSTAKA}

Asyhari, A., \& Hartati, R. (2015). Profil Peningkatan Kemampuan Literasi Sains Siswa Melalui Pembelajaran Saintifik. Jurnal Ilmiah Pendidikan Fisika AlBiRuNi, $\quad 4(2)$, 179191.https://doi.org/10.24042/jpifalbiruni.v $\underline{4 \mathrm{i} 2.91}$

Budhiman, A. (2017). Gerakan Penguatan Pendidikan Karakter. Jakarta: Kementerian Pendidikan dan Kebudayaan Republik Indonesia.

Dewi, S. R., Nurmilawati, M., \& Budiretnani, D. A. (2017). Improving of scientific literacy ability using discovery learning model at the seventh grade students of state JHS 3 Ngronggot, NganjukIndonesia. Jurnal Pendidikan Biologi Indonesia, 3(3), 266-271. https://doi.org/10.22219/jpbi.v3i3.4597

Dragoş, V., \& Mih, V. (2015). Scientific Literacy in School. Procedia - Social and Behavioral Sciences, 209(July), 167-172. https://doi.org/10.1016/j.sbspro.2015.11.2 73

Emaliana, I. (2020). Pelatihan Penulisan Karya Ilmiah bagi Guru MGMP Bahasa Inggris SMA/MA se-Malang Raya. Dinamisia: Jurnal Pengabdian Kepada Masyarakat, $3(2)$, 273-279. https://doi.org/10.31849/dinamisia.v3i2.3 $\underline{380}$
Faisal, M., Hotimah, Nurhaedah, AP, N., \& Khaerunnisa. (2020). Peningkatan Kompetensi Guru Sekolah Dasar dalam Mengembangkan Bahan Ajar Digital di Kabupaten Gowa. Jurnal Publikasi Pendidikan, 10(3), 266-270. http://dx.doi.org/10.26858/publikan.v10i3 .16187

Herlanti, Y., Mardiati, Y., Rahmawati, R., Putri, A. M. K., Jamil, N., Miftahuzzakiyah, M., Sofyan, A., Zulfiani, Z., \& Sugiarti, S. (2019). Finding Learning Strategy in Improving Science Literacy. Jurnal Penelitian Dan Pembelajaran IPA, 5(1), 59. https://doi.org/10.30870/jppi.v5i1.4902

Kemendikbud. (2017). Konsep dan Pedoman Penguatan Pendidikan Karakter Cetakan kedua. Jakarta: Kementerian Pendidikan dan Kebudayaan Republik Indonesia.

Kemendikbud. (2017). Materi Pendukung Literasi Sains. Jakarta: Kementerian Pendidikan dan Kebudayaan Republik Indonesia.

Kementerian Pendidikan dan Kebudayaan Republik Indonesia. (2017). Panduan Gerakan Literasi Nasional. Jakarta: Kementerian Pendidikan dan Kebudayaan Republik Indonesia.

Kholifah, W. T. (2020). Upaya Guru Mengembangkan Karakter Peserta Didik Sekolah Dasar Melalui Pendidikan Ramah Anak. Jurnal Pendidikan Dan Konseling (JPDK), 1(2), 135-142. https://doi.org/10.31004/jpdk.v1i2.614

McFarlane, D. A. (2013). Understanding the Challenges of Science Education in the 21st Century: New Opportunities for Scientific Literacy. International Letters of Social and Humanistic Sciences, 4(January), 35-44. https://doi.org/10.18052/www.scipress.co m/ilshs.4.35

OECD. (2015). PISA 2015 Assessment and Analytical Framework: Science, Reading, Mathematic and Financial Literacy, PISA.

Peraturan Menteri Pendidikan Nasional Republik Indonesia Nomor 16 Tahun 2007 Tentang Standar Kualifikasi Akademik dan Kompetensi Guru

Rubini, B., Pusitasari, I. D., Ardianto, D., \& Hidayat, A. (2018). Science teachers' understanding on science literacy and integrated science learning: Lesson from teachers training. Jurnal Pendidikan IPA 
Indonesia, 7(3), 259-265. https://doi.org/10.15294/jpii.v7i3.11443

Sani, R.A. (2014). Pembelajaran Saintifik untuk Implementasi Kurikulum 2013. Jakarta: Bumi Aksara.

Sunarti, E. (2005). Menggali Kekuatan Cerita. Jakarta: PT Elek Media Komputindo.

Sutjipto. (2011). Rintisan Pengembangan Pendidikan Karakter di Satuan Pendidikan. Jurnal Pendidikan dan Kebudayaan, 5(17), 501-524. https://doi.org/10.24832/jpnk.v17i5.45

Triatmanto. (2010). Tantangan Implementasi Pendidikan Karakter. Cakrawala Pendidikan, Edisi Khusus Dies Natalis UNY, $\quad 187$ 203.https://doi.org/10.21831/cp.v1i3.245

Undang-Undang Republik Indonesia Nomor 14 Tahun 2005 Tentang Guru dan Dosen. 